\title{
Could Honeybee Colony Collapse Disorder (CCD) be Due to Drones Being Hyper-Sensitive to Certain Types of DNA Damage?
}

Jacob Z Dalgaard

The University of Warwick, Coventry, England, UK

"Corresponding author: Dalgaard JZ, The University of Warwick, Coventry, Farmer Ward Road Kenilworth, Warwickshire CV82DJ, United Kingdom, Tel: 44(0)1926851170; E-mail: jzeuthendalgaard@gmail.com

Received date: August 03, 2016; Accepted date: September 14, 2016; Published date: September 22, 2016

Copyright: @ 2016 Dalgaard JZ. This is an open-access article distributed under the terms of the Creative Commons Attribution License, which permits unrestricted use, distribution, and reproduction in any medium, provided the original author and source are credited

\begin{abstract}
In old days, miners would bring canaries with them in the mines as a way of detecting dangerous levels of gas, due to birds being hyper-sensitivity to low oxygen levels. Similarly, male honeybees (drones) are likely to be hypersensitive to some types of DNA damaging agents, due to their cells being haploid. Potentially, such hyper-sensitivity, combined with the queen bee's mating behavior, could explain the general decrease in the world's honeybee populations as well as the enigmatic Honeybee Colony Collapse Disorder.
\end{abstract}

\section{Introduction}

Honeybees (Apis mellifera) belong to the group of species where their sex is determined by their cells' chromosome ploidy; queens and worker bees develop from fertilized diploid eggs (queens develop in specific cells in the comb, where the diploid larva are being fed Royal Jelly by the worker bees), while drones develop from unfertilized haploid eggs (a process called parthenogenesis) [1-4]. The sex is determined by a locus called csd (complementary sex determiner) that in diploid cells has to be hetero-zygotic in order to mediate queen/ worker bee development [5-7]. It has been estimated that 116-145 different alleles of csd gene exist in the honeybee populations worldwide [8]. If a honeybee egg is fertilized by a sperm carrying an identical allele at the csd locus (through inbreeding), then the fertilized egg will develop into a diploid male [9]. Such diploid male larvae are recognized, when they hatch, by the worker bees, which remove them from the comb and eat them [10]. Thus, only haploid males are allowed to develop. So how does the queen avoid mating with related haploid males? This is prevented by the queen's mating behavior; in her first spring she will leave the hive for a mating flight whereby she seeks genetically unrelated drones. During the flight, she can mate with up to 20 drones [11]. She stores the sperm obtained by the matings for up to three to five years (her lifespan) and will never mate again. The queen then returns to the hive, and three days later start to lay fertilized diploid eggs, thus establishing and maintaining the hive's large worker population. In the spring and summer months, the average lifespan of a worker bee is forty days, while workers born in the autumn will survive the winter and early spring. During the winter, the population of workers decreases from about approximately 35000 to 50000 per hive.

The question is what will happen if the queen is un-successful in accumulating enough good quality viable sperm, either due to fewer mating-events or due to that the drones she mates with are either partly or completely infertile? The prediction is that the queen will be able to lay viable unfertilized eggs (these can only develop into drones), while the fertilized eggs she lays are likely to be unable to develop or develop into worker bees with decreased fitness. As a consequence, the population of the hive's worker bees will plummet. This could indeed be what happens during Honeybee Colony Collapse Disorder (CCD); here, without any visual warning signs or the presences of deceased or dead bees, the size of the worker bee population suddenly decreases and the hive collapse [12]. Indeed, queen failure has been proposed as a particular significant cause of Honeybee decline [13,14] and low sperm-viability has been proposed as a potential underlying cause [13,15-17].

Why would haploid drones be more sensitive to certain DNA damaging agents and why could such sensitivity lead to drone death or infertility? DNA damaging agents can damage the DNA in many different ways. Some agents mostly modify the bases or the sugars of the DNA and damages of these types are mainly repaired by base excision or nucleotide excision repair. Such repair involves the removal of the damaged base/nucleotide followed by repair by DNA synthesis [18-22]. However, other types of DNA damage, such as damage caused by free radicals, ionizing radiation, in some cases UV light, as well as, some damage caused by reactive chemical compounds, can in some cases either directly or indirectly lead to the formation of doublestranded breaks (DSBs) in the DNA. DSBs can only efficiently be repaired error-free by a process called DNA recombination that utilizes a homologues chromosome or a homologues ectopic sequence for the repair [23]. While diploid cells are, since they possess two homologues copies of each chromosome, able to mediate homologous recombination both in G1, S and G2 phases of the cell-cycle, haploid cells can only mediate homologues recombination in the G2 cell-cycle phase. The reason being that in the G2 phase DNA synthesis has completed the synthesis of the two set of homologues sister chromatids. However, if the DSB is formed in the genome of a haploid cell in G1 or during S-phase (if the break happens in front of a replication fork), then the damage, due to the absences of a homologues chromosome sequence, will lead to genetic instability through mutations and/or gross chromosomal rearrangements and can potentially cause cell death. In case of Fission Yeast, another haploid organism, the haploid cells deals with this problem by having a short G1, where homologues recombination pathways are repressed and an error-prone ligase mediated repair pathway called non-homologous end-joining (NHEJ) is up-regulated, and a long G2 cell-cycle phase, where homologues recombination pathways are up-regulated and NHEJ is repressed [24]. Thus, in G2, Fission yeast cells are able to 
efficiently repair DSB by recombination with the homologues sister chromatid. Honeybee's drones may or may not have evolved a similar cell-cycle control as Fission Yeast in order to better survive DNA damage of the DSB type. But even if drone cells do have a short G1 and a long G2 cell-cycle phase, DSBs will be detrimental in rapidly diving haploid drone tissues such as the gonads. This is due to the frequent G1 and S-phases in such tissues and thus DSBs will lead to decrease sperm viability/quality and potentially infertility of the drone.

So what could the culprits be in the environment that could cause such DNA damage? Well, the answer would anything thing that directly or indirectly cause double- or single-stranded breaks in the DNA (a single-stranded break can be converted into a double-stranded break during S-phase DNA replication [25]) or that cause a type of damage that lead to stalled replication forks during S-phase DNA replication. The latter is because stalled/broken replication forks can also be repaired by a process that involved recombination with a homologous chromosome reviewed by [26]. Thus, such environmental factors could include reactive chemical compounds, as well as, ionizing radiation and UV light. Recent publications have indeed shown that some insecticides (Neonicotinoids and Friponil) can cause reduced sperm viability and quantities for Honeybee drones thus affecting the reproductive potential of the queens and therefore Honeybee colonies sustainability $[27,28]$. Whether or not this is due to DNA damage of the DSBs or stalled replication-forks caused by these insecticides is still unknown. Here it should be noted that most biological systems (mammalian cell cultures) currently being used to detect whether a compound is mutagenic or not, are likely to be fairly resistant to DNA damage of the DSB type. This is because mammalian cells are diploid, and therefore not suitable for predicting whether drones would be hypersensitive to a compound. It should also be noted, that searches of PubMed were unable to find any literature addressing the sensitivity of Honey Bee drones to DNA damaging agents.

Finally, it has alternatively been proposed that Honeybee viruses and other pathogens are a possible cause of CCD [29,30]. However, if pathogens are implicated, it is not in conflict with the proposal presented here. CCD might have more than one cause and several factors might have a cumulative effect on a hive's fitness. Thus, my opinion is that it is highly important to establish whether indeed Honeybee drones are hyper-sensitive to some types of DNA damage.

\section{References}

1. Petrunkewitsch A (1901) Die Richtungskörper und ihr schichsal im befruchteten un unbefruchteten bienenei. Zool Jahrb Abt Anat Ontog 14 573-608.

2. Nachtsheim H (1913) Cytologische studien über die geschlechtsbestimmung bei der honigbiene (Apis mellifica L.) Arch Zellforsch 11: 170-239.

3. Mackensen O (1951) Viability and sex determination in the honey bee (Apis Mellifera L.). Genetics 36: 500-509.

4. Crozier RH (1971) Heterozygosity and sex determination in haplodiploidy. Am Nat 105: 399-412.

5. Hasselmann M, Fondrk MK, Page RE, Beye M (2001) Fine scale mapping in the sex locus region of the honey bee (Apis mellifera). Insect Mol Biol 10: 605-608.

6. Hasselmann M, Beye M (2004) Signatures of selection among sexdetermining alleles of the honey bee. Proc Natl Acad Sci U S A 101: 4888-4893.

7. Beye M, Hasselmann M, Fondrk MK, Page RE, Omholt SW (2003) The gene csd is the primary signal for sexual development in the honeybee and encodes an SR-type protein. Cell 114: 419-429.
8. Lechner S, Ferretti L, Schoning C, Kinuthia W, Willemsen D, et al. (2014) Nucleotide variability at its limit? Insights into the number and evolutionary dynamics of the sex-determining specificities of the honey bee Apis mellifera. Mol Biol Evol 31: 272-287.

9. Woyke J (1965) Genetic proof of the origin of drones from fertilized eggs of hte honeybee. J Apic Res 4: 7-11.

10. Woyke J (1963) What happens to diploid drone larvae in a honeybee colony? J Apic Res 2: 73-75.

11. Tarpy DR, Delaney DA, Seeley TD (2015) Mating frequencies of honey bee queens (Apis mellifera L.) in a population of feral colonies in the Northeastern United States. PLoS One 10: e0118734.

12. Vanengelsdorp D, Evans JD, Saegerman C, Mullin C, Haubruge E, et al. (2009) Colony collapse disorder: a descriptive study. PLoS One 4: e6481.

13. Van Engelsdorp D, Hayes J, Underwood RM, Pettis J (2008) A survey of honey bee colony losses in the U.S., fall 2007 to spring 2008. PLoS One 3: e4071.

14. Brodschneider R, Moosbeckhofer R, Crailsheim K (2010) Surveys as a tool to record winter losses of honey bee colonies: A two year case study in Austia and South Tyrol. J Apic Res 49: 23-30.

15. Jonhson RM, Dahlgren L, Siegfried BD, Ellis MD (2013) Effect of in-hive miticides on drone honey bee survival and sperm viability. J Apic Res 52: 88-95.

16. Thompson HM, Wilkins S, Battersby AH, Waite RJ, Wilkinson D (2005) The effects of four insect growth-regulating (IGR) insecticides on honeybee (Apis mellifera L.) colony development, queen rearing and drone sperm production. Ecotoxicology 14: 757-769.

17. Rangel J, Tarpy DR (2016) In-hive miticides and their effect on queen supersedure and colony growth in the honey bee (Apis mellifera). J Environ Anal Toxicol 6: 377.

18. Wood RD (1996) DNA repair in eukaryotes. Annu Rev Biochem 65: 135-167.

19. Sancar A, Lindsey-Boltz LA, Unsal-Kaçmaz K, Linn S (2004) Molecular mechanisms of mammalian DNA repair and the DNA damage checkpoints. Annu Rev Biochem 73: 39-85.

20. Spivak G (2015) Nucleotide excision repair in humans. DNA Repair (Amst) 36: 13-18.

21. Spivak G, Ganesan AK (2014) The complex choreography of transcription-coupled repair. DNA Repair (Amst) 19: 64-70.

22. Wyrick JJ, Roberts SA (2015) Genomic approaches to DNA repair and mutagenesis. DNA Repair (Amst) 36: 146-155.

23. Mehta A, Haber JE (2014) Sources of DNA double-strand breaks and models of recombinational DNA repair. Cold Spring Harb Perspect Biol 6: a016428.

24. Ferreira MG, Cooper JP (2004) Two modes of DNA double-strand break repair are reciprocally regulated through the fission yeast cell cycle. Genes Dev 18: 2249-2254.

25. Cortes-Ledesma F, Aguilera A (2006) Double-strand breaks arising by replication through a nick are repaired by cohesin-dependent sisterchromatid exchange. EMBO Rep 7: 919-926.

26. Yeeles JT, Poli J, Marians KJ, Pasero P (2013) Rescuing stalled or damaged replication forks. Cold Spring Harb Perspect Biol 5: a012815.

27. Kairo G, Provost B, Tchamitchian S, Ben Abdelkader F, Bonnet M, et al. (2016) Drone exposure to the systemic insecticide Fipronil indirectly impairs queen reproductive potential. Sci Rep 6: 31904.

28. Straub L, Villamar-Bouza L, Bruckner S, Chantawannakul P, Gauthier L, et al. (2016) Neonicotinoid insecticides can serve as inadvertent insect contraceptives. Proc Biol Sci 283.

29. Cox-Foster DL, Conlan S, Holmes EC, Palacios G, Evans JD, et al. (2007) A metagenomic survey of microbes in honey bee colony collapse disorder. Science 318: 283-287.

30. Cornman RS, Tarpy DR, Chen Y, Jeffreys L, Lopez D, et al. (2012) Pathogen webs in collapsing honey bee colonies. PLoS One 7: e43562. 